\title{
Az évjárat és néhány agrotechnikai tényezó hatása a kukorica termésére csernozjom talajon
}

\author{
LENTE ÁDÁM-PEPÓ PÉTER \\ Debreceni Egyetem AMTC, Növénytudományi Intézet, Debrecen
}

\begin{abstract}
Összefoglalás
Tartamkísérletben, csernozjom talajon, a Hajdúságban (Kelet-Magyarország) vizsgáltuk néhány agrotechnikai tényezô (tôszám, tápanyagellátás), néhány kártevô és kórokozó (kukorica bogár (Diabrotica virgifera virgifera LeConte), kukoricamoly (Ostrinia nubilalis Hbn.), csôfuzárium (Fusarium spp.), valamint az évjárat (eltérő vízellátottságú évek: 2007. év = aszályos, 2008. év = kedvezô) hatását a kukorica termésére különböző vetésváltási rendszerekben (mono-, bi- és trikultúra). A vizsgálatokat nem öntözött körülmények között, csernozjom talajon végeztük. Vizsgálati eredményeink azt bizonyították, hogy az évjárat vízellátottsága, mint abiotikus stressz tényezô volt a legnagyobb hatással a kukorica termésére, valamint meghatározta az optimális tôszámot és trágyaadagot. Aszályos évjáratban (2007. év) a kukorica termésmaximuma 3874-5681 kg/ha (mono), 7156-7929 $\mathrm{kg} / \mathrm{ha}$ (bi), 7214-8192 kg/ha (tri), kedvezó vízellátottságú évben pedig 12 902-13 787 $\mathrm{kg} / \mathrm{ha}$ (mono), 13 974-14 $603 \mathrm{~kg} / \mathrm{ha}$ (bi) és $13594-14839 \mathrm{~kg} / \mathrm{ha}$ (tri) intervallumban mozgott nem öntözött feltételek között. Az ökológiai stressz (vízhiány) okozta terméscsökkenés monokultúrában 9,0 t/ha, bikultúrában 7,0 t/ha, trikultúrában pedig 6,0 t/ha körül változott. A kukorica optimális tôszámát és trágyaadagját mind az ökológiai stressz (vízhiány), mind az agrotechnikai stresszhatás (vetésváltás) befolyásolta. Aszályos évjáratban (2007. év) a 40 ezer/ha (mono, bi, tri), kedvezó vízellátottságú évjáratban a 60 ezer/ha (mono) és 80 ezer/ha (bi és tri) tőszám esetében kaptuk a termésmaximumokat. Az évjárat és a vetésváltás egyaránt módosította az optimális trágyaadagot. A 2007. év idôjárása miatt a növényegészségügyi értékek kedvező szinten mozogtak, a csőfuzárium-fertôzöttség 0,9-3,4\%, a molyfertőzöttség 2,1-4,5\% között változott, míg a kukoricabogár által okozott növénydôlést nem tapasztaltunk. Ezzel szemben a csapadékos évjáratban a csố-
\end{abstract}


fuzárium-fertőzötség értéke 1,0-3,9\%, a molykártétel értéke pedig 3,2-6,3\% között alakult. 2008-ban monokultúrában jelentôs kukoricabogár kártételt is tapasztaltunk. A Diabrotica által okozott növénydőlés (12,3-62,2\%) között változott, kezelésektől függóen.

Kulcsszavak: kukorica, évjárat, vetésváltás, tőszám, tápanyagellátás, kórokozók, kártevők

\title{
The effect of crop year and certain agrotechnical factors on maize yield on chernozem soil
}

\author{
Á. LENTE-P. PEPÓ \\ University of Debrecen, Centre of Agricultural Sciences and Engineering, \\ Institute of Crop Sciences, Debrecen
}

\begin{abstract}
Summary
We examined the effect of some agrotechnical factors (plant number, nutrient supply), some pests and pathogens (corn rootworm (Diabrotica virgifera virgifera LeConte), European corn borer (Ostrinia nubilalis Hbn.), corn cob fusarium (Fusarium spp.) and crop year (years with different levels of water supply: 2007: drought, 2008: favourable water supply) on maize yield in different crop rotation schemes (mono, bi-and triculture). We carried out examinations within non-irrigated conditions on chernozem soil. Our results showed that the degree of water supply in the given crop year was an abiotic stress factor and therefore it had the greatest effect on maize yield, whereas it also determined optimal plant number and fertiliser doses. In a drought year (2007), the maximum yield of maize was 3874-5681 $\mathrm{kg} \mathrm{ha}^{-1}$ (monoculture), 7156-7929 $\mathrm{kg} \mathrm{ha}^{-1}$ (biculture), 7214-8192 $\mathrm{kg} \mathrm{ha}^{-1}$ (triculture), whereas in a year with favourable water supply it was 12 902-13 787 $\mathrm{kg} \mathrm{ha}^{-1}$ (monoculture), $13974-14603 \mathrm{~kg} \mathrm{ha}^{-1}$ (biculture) and $13594-14839 \mathrm{~kg} \mathrm{ha}^{-1}$ (triculture) within non-irrigated conditions. The yield drop caused by ecological stress (water shortage) was $9.0 \mathrm{~kg} \mathrm{ha}^{-1}$ in monoculture, $7.0 \mathrm{~kg} \mathrm{ha}^{-1}$ in biculture and $6.0 \mathrm{~kg} \mathrm{ha}^{-1}$ in triculture. The optimal plant number and fertiliser dose of maize was affected both by ecological stress (water shortage) and agrotechnical stress effect (crop rotation). In a drought year (2007), we observed maximum yields in the case of the following plant numbers: 40 thousand plants ha' ${ }^{-1}$ (mono-, bi-, triculture), whereas in a year with favourable water supply, it was 60 thousand plants ha ${ }^{-1}$ (monoculture) and 80 thousand plants ha ${ }^{-1}$ (bi- and
\end{abstract}


triculture). Both crop year and crop rotation modified optimal fertiliser doses. Due to the weather in 2007 , crop health values were at favourable levels, the extent of fusarium infection was between 0.9-3.4\%, whereas that of European corn borer was between $2.1-4.5 \%$. We did not observe any lodging caused by corn rootworm. As opposed to this, the value of fusarium infection was $1.0-3.9 \%$ and that of European corn borer was $3.2-6.3 \%$ in a wet crop year. In 2008, we observed significant damage caused by corn rootworm in monoculture. The lodging caused by Diabrotica was between $12.3-62.2 \%$, depending on the given treatment.

Key words: maize, crop year, crop rotation, plant number, nutrient supply, pathogens, pests

\section{Bevezetés és irodalmi áttekintés}

A kukorica az egyik legfontosabb takarmánynövény, felhasználása, hasznosíthatósága igen sokoldalú. Keményítőben gazdag szemtermése fontos abraktakarmány, valamint ipari felhasználásra, sôt közvetlen emberi fogyasztásra is alkalmas.

A kukorica igen nagy produktivitású növény, amit több mint 1 millió hektáron termesztenek Magyarországon. Termésátlaga az évjárattól és a termesztés színvonalától függôen 4-7 t/ha között változik (Pepó et al. 2006a). Az idôjárási szélsôségek egyre gyakoribb megjelenéséből arra következtethetünk, hogy a klímaváltozás valódi problémává nô, ami az aszályos évek gyakoriságát okozhatja hazánkban (Sárvári 2005). Az extrém aszályos évben (1990. év) a takarmánykukorica szemtermése felére zuhant a növekvő NP trágyázással (Kádár és Márton 2007), ezenkívül az optimálistól nagyobb tôszám is növeli a vízigényt, valamint az aszályra való érzékenységet (Sárvári 2009).

Nagy (2007) több mint két évtizedes kísérletei bizonyítják, hogy az évjárat nagyban befolyásolja az évenkénti termésingadozást, amely nagysága akár 7 t/ha is lehet. A legnagyobb terméscsökkenés monokultúrában volt tapasztalható a 2007. évben, amikor is a trágyaadagok növelése további termésdepressziót okozott (Pepó et al. 2008).

A kukorica sikeres termesztése szempontjából különösen fontos a tápanyagellátás, amiből kiemelendő a nitrogén és egyéb makroelemek harmónikus visszapótlása. Ennek optimális értékét befolyásolhatja a talaj, a klimatikus tényezôk, a genotípus, valamint az agrotechnikai tényezők (Bocz és Nagy 1981). 
Berzsenyi és Dang (2008) eredményei szerint kedvezó évjáratban a legmagasabb termést $120 \mathrm{~kg}$ N/ha-nál realizálták, míg kedvezőtlen évjáratú évben az optimális trágyaszint $60 \mathrm{~kg} \mathrm{~N} /$ ha volt.

A kukoricatermesztés sikerességét alapvetôen meghatározza a kórokozók és kártevők elleni védekezés. A kukoricabogár (Diabrotica virgifera virgifera LeConte) hazánkban a Romániával és Jugoszláviával határos területeken jelent 1995-ben és a 2000-es évek elejére hazánk egész területén elterjedt (Princzinger 1996, Princzinger et al. 2002). Ennek következtében jelentősen megnőtt a kukoricabogár lárvája által okozott növénydőléses kártétel (Ripka et al. 2000). Széll et al. (2005) szerint a kukorica önmaga utáni termesztés évei számának növekedése többszörös megbízhatósággal fokozta a növénydólést, valamint jelentős mértékben csökkentette a termés mennyiségét.

Keszthelyi et al. (2002) szerint hazánkban a kukorica egyik legjelentôsebb kártevôje a kukoricamoly. Pálfy (1983) a kukoricamoly elsôdleges kártételének tekinti a közvetlen terméscsökkenést, valamint másodlagos kártételrôl beszél, amikor a kártétel hatására elszaporodnak a fitopatogén mikroorganizmusok.

A Fusarium fajok jelentôsen csökkentik a kukorica terméseredményét és minôségét a gyökér-, cső-, szempenészesedéssel, korhadással (Pepó et al. 2006b). A kukorica betegségei közül kórtani szempontból a Fusarium fajok elôfordulása lehet kihatással jelentôs mértékben a terméseredményekre. A betegség tünetei az egész tenyészidőszakban megfigyelhetők (Clements et al. 2003).

\section{Anyag és módszer}

A vizsgálatokat a Debreceni Egyetem AMTC Növénytudományi Intézetének Látóképi Kísérleti Telepén végeztük. A kísérleti telep Debrecentől 15 km-re nyugati irányban fekszik, a Hajdúsági Löszháton. A kísérlet talaja löszön képződött, mély humuszrétegú alföldi mészlepedékes csernozjom talaj. A kísérleti terület talaja jó kultúrállapotú, középkötött, talajfizikailag a vályog kategóriába sorolható.

A tartamkísérlet 1983-ban került beállításra. Vizsgálataink a 2007. és 2008. éveket tartalmazzák.

A kísérlet három vetésváltási rendszert tartalmaz: monokultúra (kukorica), bikultúra (búza-kukorica) és trikultúra (borsó-búza-kukorica).

A kezelésekben öt tápanyagszintet és három állománysûrúségi szintet al- 
kalmaztunk. Az öt tápanyagszint a következő: kontroll (kezeletlen), $\mathrm{N}_{60} \mathrm{P}_{45} \mathrm{~K}_{45}$, $\mathrm{N}_{120} \mathrm{P}_{90} \mathrm{~K}_{90}, \mathrm{~N}_{180} \mathrm{P}_{135} \mathrm{~K}_{135}, \mathrm{~N}_{240} \mathrm{P}_{180} \mathrm{~K}_{180}$. A három állománysûrúségi érték 40 ezer/ha, 60 ezer/ha valamint 80 ezer/ha volt. A kísérleti parcellák véletlen blokk elrendezéssel, 4 ismétlésben lettek beállítva.

A vegetációs idôszakban növényegészségügyi megfigyeléseket is végeztünk, amely során a kukoricabogár, a kukoricamoly és a csőfuzárium kártételét vizsgáltuk az egyes kezelésekben. A megfigyelések során a fertőzöttségi értékeket a fertőzött csövek száma alapján kaptuk meg. Emellett kéttényezős varianciaanalízist végeztünk az eltérô vetésváltási rendszerekben, tápanyagellátás és tőszám vonatkozásában.

Az 1. táblázatban az összehasonlított száraz (2007.) és kedvezôen csapadékos (2008.) évek tenyészidôszakában lehullott csapadék értékek, valamint ugyanazon hónapok hőmérséklet adatai találhatók.

1. táblázat. Fontosabb meteorológiai adatok (Debrecen, 2007-2008)

\begin{tabular}{|c|c|c|c|c|c|c|}
\hline \multirow{2}{*}{$\begin{array}{l}\text { Hónap } \\
\text { (1) }\end{array}$} & \multicolumn{3}{|c|}{$\begin{array}{c}\text { Csapadék } \\
\text { (2) }\end{array}$} & \multicolumn{3}{|c|}{$\begin{array}{c}\text { Hőmérséklet } \\
\text { (3) }\end{array}$} \\
\hline & 2007 & 2008 & $\begin{array}{c}30 \text { éves } \\
\text { átlag } \\
\text { (4) }\end{array}$ & 2007 & 2008 & $\begin{array}{c}30 \text { éves } \\
\text { átlag } \\
\text { (4) }\end{array}$ \\
\hline Március (5) & 14,0 & 41,7 & 33,5 & 9,1 & 16,8 & 5,0 \\
\hline Április (6) & 3,6 & 74,9 & 42,4 & 12,6 & 11,4 & 10,7 \\
\hline Május (7) & 54 & 47,6 & 58,8 & 18,4 & 16,8 & 15,8 \\
\hline Június (8) & 22,8 & 140,1 & 79,5 & 22,2 & 20,6 & 18,7 \\
\hline Július (9) & 39,7 & 144,9 & 65,7 & 23,3 & 20,4 & 20,3 \\
\hline Augusztus (10) & 77,6 & 34,2 & 60,7 & 22,3 & 20,6 & 19,6 \\
\hline Szeptember (11) & 86,1 & 42,2 & 38,0 & 14,0 & 14,8 & 15,8 \\
\hline Összesen/átlag (12) & 297,8 & 525,6 & 378,6 & 17,4 & 17,3 & 15,1 \\
\hline
\end{tabular}

Table 1. Main meteorological data (Debrecen, 2007-2008). (1) Month, (2) Precipitation, (3) Temperature, (4) 30 years' average, (5) March, (6) April, (7) May, (8) June, (9) July, (10) August, (11) September, (12) Sum/average.

\section{Eredmények és értékelés}

A kukorica nagy tápanyagigényú kultúra, amely jól hasznosítja a talajban lévő, valamint a mesterségesen kijutatott tápanyagokat. A trágyázás hatékonyságát nagy- 
mértékben befolyásolják a talajtulajdonságok, a vízellátás, valamint a biológiai és agrotechnikai tényezők is.

A Debreceni Egyetem Növénytudományi Intézetének látóképi telepén kiváló feltételek mellett, 25 éve beállított tartamkísérletben vizsgáltunk néhány agrotechnikai tényezôt (tápanyagellátás, tôszám) különböző vetésváltási rendszerekben (mono-, bi- és trikultúra). A 2007. év igen száraz (kedvezôtlen), a 2008. év pedig csapadékos (kedvezô) volt. 2007-ben a márciustól júniusig tartó idôszakban a csapadék mennyisége elmaradt a 30 éves átlagtól $(80,8$ mm-rel kevesebb csapadék hullott). A 2008-ban ezzel szemben a tenyészidőszak minden hónapjában vagy átlagos, vagy az átlagot meghaladó volt, így a vegetációs periódusban 147,0 mm-rel több volt a csapadék. Mindkét tenyészidószakban a havi hômérsékleti értékek meghaladták a sokévi átlagot (2007-ben $2,3{ }^{\circ} \mathrm{C}$-kal, 2008-ban $2,2^{\circ} \mathrm{C}$-kal volt a tenyészidó átlaghőmérséklete magasabb). Ezen két igen eltérô év lehetôséget nyújtott arra, hogy vizsgáljuk az évjárat hatását a kukorica kórokozóinak és kártevőinek megjelenésére, kártételére, valamint az évjárat és agrotechnikai elemek interaktív hatásait.

A kedvezôtlen vetésváltás okozta abiotikus és biotikus stresszhatás nagymértékben volt tapasztalható a 2007. száraz évben, amikor monokultúrás termesztésben a termésmaximumok $3874-5681 \mathrm{~kg} / \mathrm{ha}$ között változtak ( 2 . táblázat). Ugyanezen évben bikultúrában $7156-7929 \mathrm{~kg} / \mathrm{ha}$, míg trikultúrában $7214-8192 \mathrm{~kg} /$ ha között változott a kukorica termésmaximuma trágyaadagtól és tôszámtól függóen. Ezzel szemben a 2008. (csapadékos) évben ugyanez a kedvezótlen hatás jóval kisebb mértékben volt tapasztalható. 2008-ban a termésmaximumok a következóképpen alakultak: $12902-13787 \mathrm{~kg} /$ ha (monokultúra), $13974-14603 \mathrm{~kg} / \mathrm{ha}$ (bikultúra) és $13594-14839 \mathrm{~kg} / \mathrm{ha}$ (trikultúra).

A nem trágyázott (kontroll) parcellákon a száraz 2007. évben minden tôszám mellett a legnagyobb terméseket a trikultúra vetésváltás esetében takarítottuk be (a termések 6526-7938 kg/ha között változtak). A kedvezó 2008. évben jól érvényesült a csernozjom talaj kiváló tápanyagszolgáltató képessége. Ebben az évben a kontroll kezelés termésmaximumait a bikultúra vetésváltás adta, amely értékek $11328-12128 \mathrm{~kg} /$ ha között változtak.

A talaj természetes tápanyagainak és a mútrágyák hatóanyagának érvényesülését alapvetôen a talajtulajdonságok mellett a vegetációs periódus vízellátása határozza meg. A száraz 2007. évben, a korlátozott mennyiségú csapadék hatására a kisebb dózisban kijuttatott tápanyagok kedvezóbb hatást értek el, mint az extrém nagy trágyaadagok, amelyek kedvezőtlenül hatottak a növények fiziológiai folyamataira. 


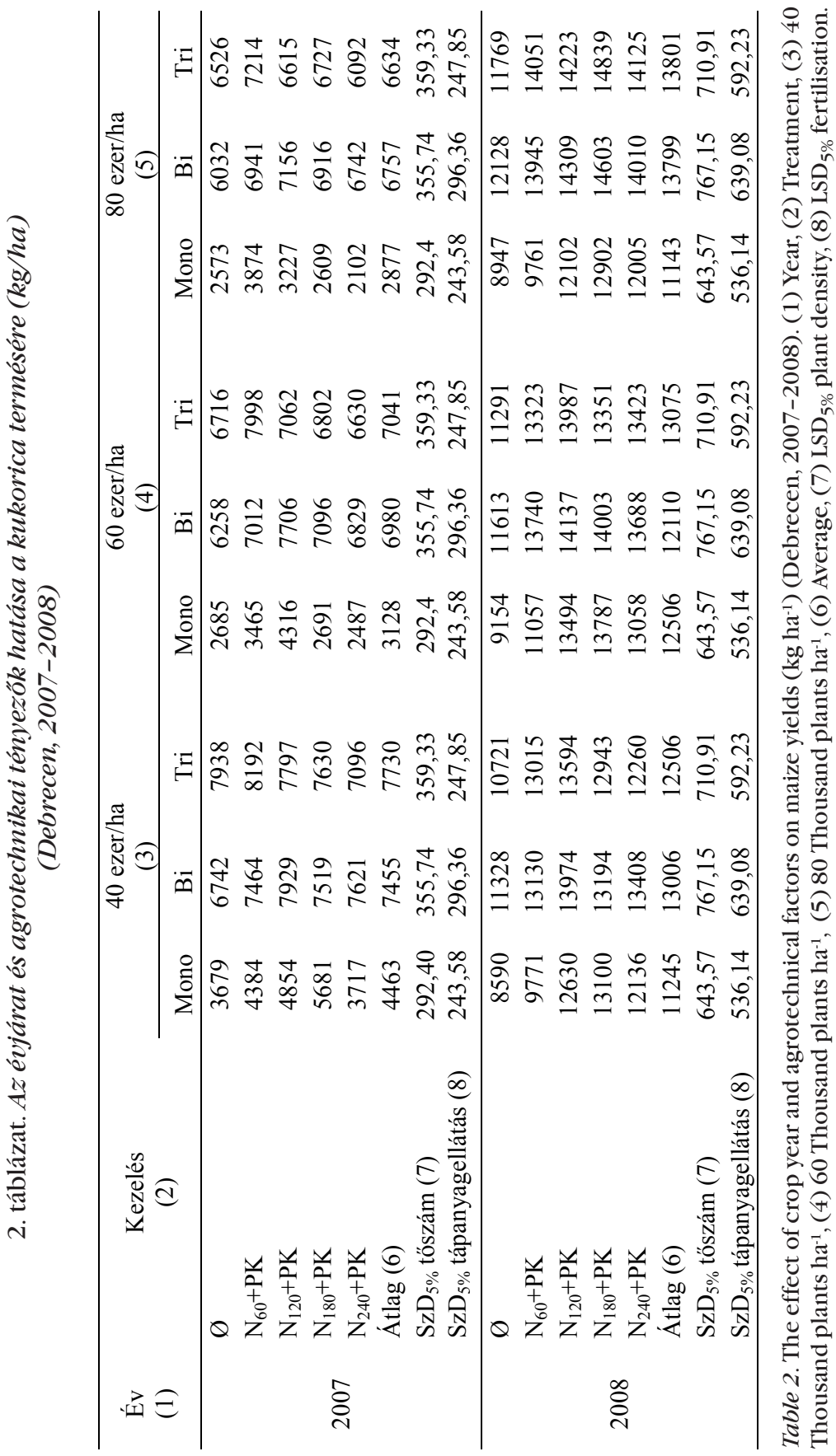


2007-ben a $\mathrm{N}_{240}+$ PK trágyaadag hatására 40 ezer/ha tôszámnál trikultúrában $842 \mathrm{~kg} / \mathrm{ha}, 60$ ezer/ha tôszámnál monokultúrában $198 \mathrm{~kg} / \mathrm{ha}$, trikultúrában $86 \mathrm{~kg} / \mathrm{ha}, 80$ ezer/ha tôszámnál monokultúrában $471 \mathrm{~kg} / \mathrm{ha}$, míg trikultúrában $434 \mathrm{~kg} /$ ha volt a terméscsökkenés a kontroll parcellákhoz viszonyítva. Ezt a hatást abiotikus stressznek tekinthetjük (Bocz 1976). A kedvezó vízellátottságú 2008-ban ezzel szemben minden vetésváltásban és tószám mellett a legalacsonyabb szemtermést a kontrollkezelések adták (8590-11 769 kg/ha), amely a tartamkísérlet ellenére igen kedvezô volt. A 2008. évben a legmagasabb termést a $\mathrm{N}_{120}+$ PK trágyaszintnél értük el bi- és trikultúrában, 40 ezer/ha és 60 ezer/ha tôszám esetében is. Monokultúrában ezen két tôszám esetében a legnagyobb termést $\mathrm{N}_{180}+\mathrm{PK}$ trágyaszintnél mértük. 80 ezer/ha tôszámnál $\mathrm{N}_{120}+\mathrm{PK}$ trágyaszintnél értük el a legnagyobb termést mindhárom vetésváltási rendszerben.

A vízellátás nemcsak az optimális trágyaadagot, hanem a kukorica optimális tôszámát is jelentôsen befolyásolja. A tôszámot tekintve száraz évben a kisebb tôszám volt az optimális. Mindhárom vetésváltási rendszerben a 40 ezer/ha tôszám esetében kaptuk a maximális terméseredményeket (monokultúra $5681 \mathrm{~kg} /$ ha, bikultúra $7926 \mathrm{~kg} /$ ha és trikultúra $8192 \mathrm{~kg} / \mathrm{ha}$ ). Minden vetésváltási rendszerben a legkisebb termésmennyiséget 80 ezer/ha tôszám mellett kaptuk.

Kedvezô vízellátottságú évben (2008. év), monokultúrában 60 ezer/ha tôszám mellett kaptuk a termésmaximumot (13 $787 \mathrm{~kg} / \mathrm{ha}$ ) míg bikultúrában és trikultúrában a legnagyobb termést 80 ezer/ha tôszám mellett értük el 14603 $\mathrm{kg} /$ ha (bikultúra) és $14839 \mathrm{~kg} / \mathrm{ha}$ (trikultúra) terméseredménnyel.

Növényegészségügyi szempontból nézve a 2007. száraz évben a kórokozók és kártevők által okozott kár nem tekinthetô jelentősnek. Kukoricabogár lárvája által okozott növénydőlés nem volt tapasztalható, még monokultúrás termesztésben sem. Ennek oka a júniusban lehullott kevés csapadék lehet, ami 40 mm-rel marad el a 30 éves átlagtól, párosulva a sokévi átlagnál magasabb $\left(+3,5^{\circ} \mathrm{C}\right)$ havi átlaghômérséklettel. Ennek következtében a talaj felsố rétege olyan mértékben száradt ki, hogy jelentôs volt a kártevook lárváinak a pusztulása, mivel nem találták meg a kedvezô életfeltételeket. Ezzel szemben a 2008. évben tapasztalt megdôlés monokultúrában átlagosan meghaladta a 30\%-ot, ami jelentős kártételként értékelhető (3. táblázat). Bi- és trikultúrában 2008-ban sem mértünk kártételt. A legnagyobb növénydólést a kontroll parcellákon mértük, ami 40 ezer/ha tôszámnál 28,0\%, 60 ezer/ha tôszámnál 37,2\%, 
míg a legmagasabb (80 ezer/ha) tôszám esetében $62,2 \%$ volt. Legalacsonyabb volt a dôlés mértéke a legnagyobb trágyaszint esetében, növekvố tôszám mellett ezek a következók voltak: 12,3, 15,3 és 37,2\%. Megállapítható, hogy mind a tápanyagszint, mind a tôszám jelentôsen befolyásolta a Diabrotica által okozott növénydôlés nagyságát. A 40 ezer/ha és 60 ezer/ha közötti kártétel különbsége 8,1\%, de ugyanez a különbség 40 ezer/ha és 80 ezer/ha tôszám között már 31,7\%-ot ér el. A tápanyagszintek növelésével jelentôs csökkenés tapasztalható mindhárom tőszám mellett. 40 ezer/ha tôszámnál a kontroll parcellákon 28,0\%-os dólést tapasztaltunk, míg ez az érték a $\mathrm{N}_{240}+\mathrm{PK}$ kezelésben 12,3\%-ra csökkent. Ez a kártétel csökkenés 60 ezer/ha és 80 ezer/ha tôszám mellett 21,9 és $25,0 \%$ volt. A termésmaximumokat és a növénydőlés értékeit összevetve megállapítható, hogy a legmagasabb terméseredményeket nem a legalacsonyabb kártételi szintnél kaptuk, amiből következóen megállapítható, hogy a vizsgált agrotechnikai elemek nagyobb mértékben befolyásolták a termés nagyságát, mint a kukoricabogár kártétele által okozott terméscsökkenés.

3. táblázat. Az évjárat és néhány agrotechnikai tényező hatása a kukoricabogár (Diabrotica virgifera virgifera LeConte) által okozott növénydólésre (\%) (Debrecen, 2008)

\begin{tabular}{lcccccccccc}
\hline \multirow{2}{*}{$\begin{array}{c}\text { Kezelés } \\
\text { (1) }\end{array}$} & \multicolumn{3}{c}{$\begin{array}{c}40 \text { ezer/ha } \\
(2)\end{array}$} & \multicolumn{3}{c}{$\begin{array}{c}60 \text { ezer/ha } \\
(3)\end{array}$} & \multicolumn{3}{c}{$\begin{array}{c}80 \text { ezer/ha } \\
(4)\end{array}$} \\
\cline { 2 - 12 } & Mono & Bi & Tri & Mono & Bi & Tri & Mono & Bi & Tri \\
\hline$\varnothing$ & 28,0 & 0 & 0 & 37,2 & 0 & 0 & 62,2 & 0 & 0 \\
$\mathrm{~N}_{60}+\mathrm{PK}$ & 17,2 & 0 & 0 & 29,4 & 0 & 0 & 54,6 & 0 & 0 \\
$\mathrm{~N}_{120}+\mathrm{PK}$ & 19,5 & 0 & 0 & 25,6 & 0 & 0 & 48,3 & 0 & 0 \\
$\mathrm{~N}_{180}+\mathrm{PK}$ & 16,7 & 0 & 0 & 26,5 & 0 & 0 & 49,8 & 0 & 0 \\
$\mathrm{~N}_{240}+\mathrm{PK}$ & 12,3 & 0 & 0 & 15,3 & 0 & 0 & 37,2 & 0 & 0 \\
Átlag (5) & 18,7 & 0 & 0 & 26,8 & 0 & 0 & 50,4 & 0 & 0 \\
SzD $_{5 \%}$ töszám (6) & 6,24 & 0 & 0 & 6,24 & 0 & 0 & 6,24 & 0 & 0 \\
SzD $_{5 \%}$ tápanyagellátás (7) & 4,09 & 0 & 0 & 4,09 & 0 & 0 & 4,09 & 0 & 0 \\
\hline
\end{tabular}

Table 3. The effect of crop year and agrotechnical factors on plant lodging caused by corn rootworm (Diabrotica virgifera virgifera) (Debrecen, 2008). (1) Treatment, (2) 40 Thousand plants ha-1, (3) 60 Thousand plants ha' ${ }^{-1}$, (4) 80 Thousand plants ha' ${ }^{-1}$, (5) Average, (6) LSD $\mathrm{L}_{5 \%}$ plant density, (7) $\mathrm{LSD}_{5 \%}$ fertilisation.

A kukorica másik jelentós, ugyanakkor sokkal mérsékeltebb kárt okozó kártevője a kukoricamoly. A két vizsgált év adatai alapján megállapítható, hogy a 
vizsgált évek idôjárása közötti igen nagy eltérés ellenére a kukoricamoly kártételében markáns különbség nem volt, és jelentős gazdasági kártételt egyik évben sem tapasztaltunk (1. ábra). 2007-ben 2,1 - 4,5\% között változott a kukoricamoly fertőzöttség. A legnagyobb kártételt 2007-ben a legnagyobb termést adó kezelésben tapasztaltuk (monokultúra, 40 ezer/ha, $\mathrm{N}_{180}+\mathrm{PK}$ ), 4,5\%-os fertôzéssel. Adataink szerint a vetésváltás hatására a kártétel átlagosan 1,4\%-kal csökkent. A két vizsgált évben a tápanyagszintek növekedésével a kártétel nagysága minimális növekedési tendenciát mutatott, míg a tőszámváltozást figyelembe véve a 2008. évben tapasztalható minimális növekedési tendencia, addig a száraz 2007. évben ilyen tendenciát nem tapasztaltunk. A 2008. évben a fertôzés nagysága 3,2-6,3\% között volt, a legmagasabb kukoricamoly-kártételt monokultúrában, 80 ezer/ha tôszámnál, $\mathrm{N}_{240}+\mathrm{PK}$ trágyaszintnél tapasztaltunk. Ez 1,45 abszolút \%-kal nagyobb kártételt jelent a száraz évhez képest, ami a 2008-ban lehullott magasabb csapadékmennyiséggel magyarázható, mivel a kukoricamoly számára kedvezőbb a meleg és csapadékos évjárat.

1. ábra. Az évjárat és agrotechnikai tényezök hatása a kukoricamoly (Ostrinia nubilalis Hbn.) fertôzöttségére (Debrecen, 2007-2008)

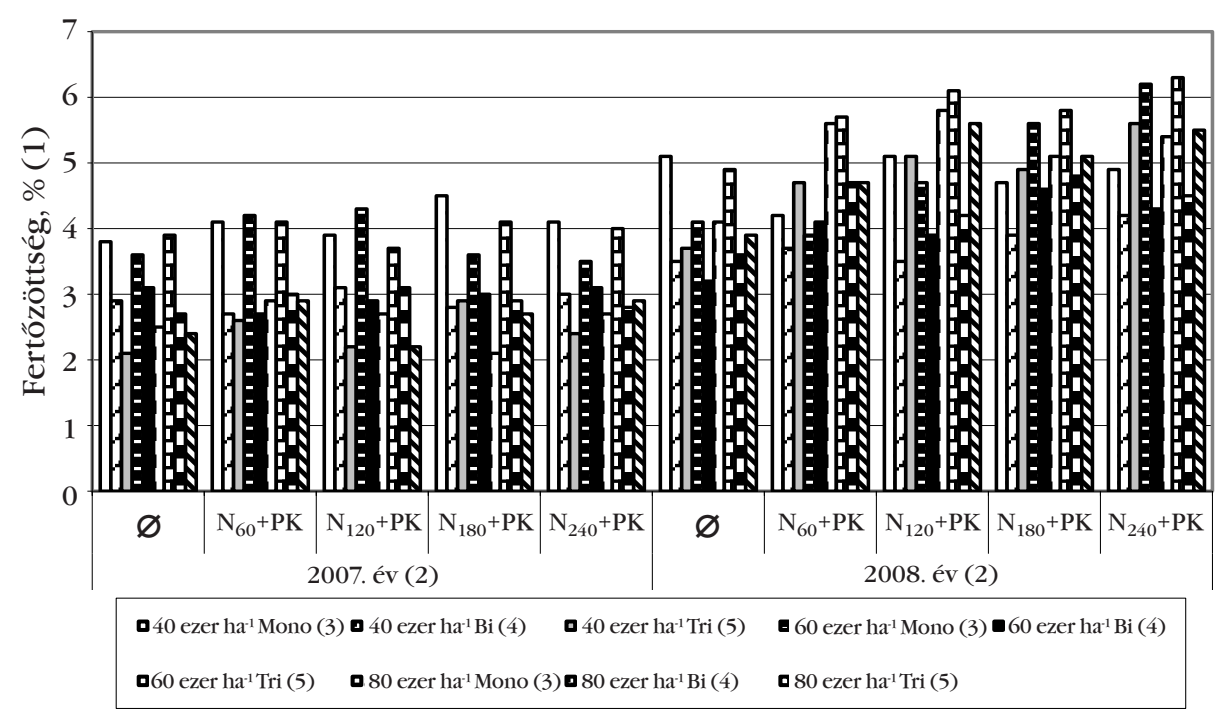

Figure 1. The effect of crop year and agrotechnical factors on the infection of corn borer (Ostrinia nubilalis) (Debrecen, 2007-2008). (1) Infection, (2) Year, (3) 40 Thousand plants ha' ${ }^{-1}$, (4) 60 Thousand

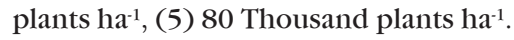


A kukorica kórokozói közül a legjelentôsebb fertőzést a Fusarium fajok okozzák. Vizsgálatainkban a 2007. és 2008. év csőfuzárium fertőzés adatai szerepelnek (2. ábra). A fertőzés mértéke egyik évben sem okozott jelentős gazdasági kárt. A 2007. évben a fertőzés minimális értéke 0,9\% volt trikultúrában, 40 ezer/ha tôszám esetében, a kontrollkezelésben, míg a legmagasabb értéket $\mathrm{N}_{240}+$ PK tápanyagellátás mellett 80 ezer/ha tôszámnál monokultúrában tapasztaltuk, ami 3,4\% volt. A 2008. évben a szélsőértékeket ugyanezen kezelések mellett kaptuk: minimum: 1,0\%, maximum: 3,9\%. A 2008. év magasabb értékeit ebben az esetben is a nagyobb csapadék mennyiséggel magyarázhatjuk, mivel a micéliumos gombák, így a Fusarium spp. fajok terjedésére kedvező hatással van a nedves évjárat. A száraz 2007. évben a legnagyobb tápanyagellátottságú parcellákon a Fusarium fajok megjelenése a csöveken 0,5-1,1 abszolút \%-kal volt magasabb a kontroll parcellákhoz viszonyítva. Ez az eltérés a csapadékos 2008. évben 1-1,9\% volt. Megfigyelhető, hogy a vetésváltás hatására a fertôzések aránya a monokultúrát és a trikultúrát összehasonlítva 2007-ben 1,1-1,4\%, míg 2008-ban 0,9-1,8\% közötti intervallumban változott.

\section{2. ábra. Az évjárat és agrotechnikai tényezôk hatása a kukorica csőfuzárium}

(Fusarium spp.) fertőzöttségére (Debrecen, 2007-2008)

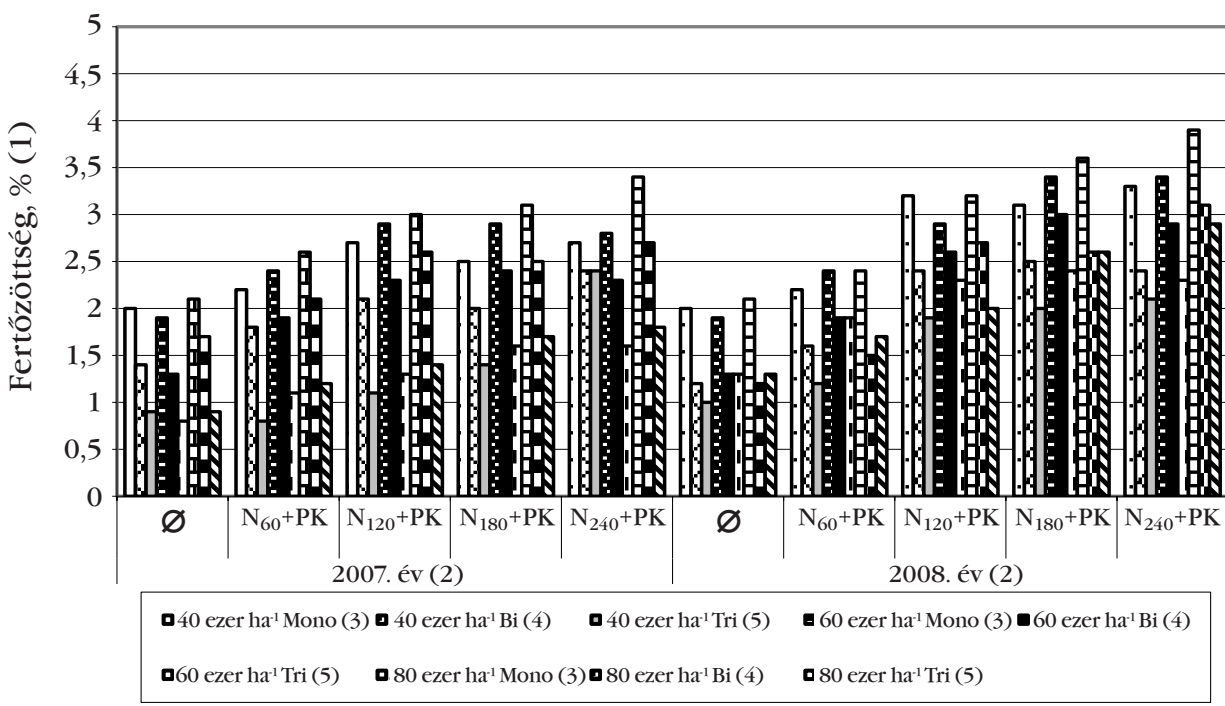

Figure 2. The effect of crop year and agrotechnical factors on infection of corn cob fusarium (Fusarium spp.) (Debrecen, 2007-2008). (1) Infection, (2) Year, (3) 40 Thousand plants ha'-1, (4) 60 Thousand plants ha-1, (5) 80 Thousand plants ha-1. 


\section{IRODALOM}

Berzsenyi, Z.-Dang, Q. L.: 2008. Effect of sowing date and $\mathrm{N}$ fertilization on the yield and yield stability of maize (Zea mays L.) hybrids in a long-term experiment. Acta Agronomica Hungarica. 56: 247-264.

Bocz E.: 1976. Trágyázási útmutató. Mezôgazdasági kiadó. Budapest.

Bocz E.-Nagy J.: 1981. A kukorica víz- és tépanyagellátásának optimalizálása és hatása a termés tömegére. Növénytermelés. 30. 6: 539-547.

Clements, J. M.-Campbell, W. K.-Maragos, M. C.-Pilcher, C.-Headrick, M. J.-Pataky, K. J.-White, G. H.: 2003. Influence of Cryl Ab protein and hybrid genotype on Fumonisin contamination and Fusarium ear rot of corn. Crop Science. 43: 1283-1293.

Kádár I.-Márton L.: 2007. Kukorica utáni kukorica trágyareakciója a mezóföldi OMTK kísérletben 1970-2006 között. Növénytermelés. 56. 5-6: 307-319.

Keszthelyi S.-Najat, A.-Fekete A.-Marczali Zs.: 2002. A kukoricamoly (Ostrinia nubilalis Hübner) lárvák növényenkénti számának és elhelyezkedésének hatása egy középérésú kukoricahibrid súly- és beltartalmi értékeire. Növényvédelem. 38. 7: $337-345$.

Nagy, J.: 2007. Evaluating the effect of year and fertilisation on the yield of mid ripening (FAO 400-499) maize hybrids. Cereal Research Communication. 35: 3. 1497-1507. Pálfy Cs.: 1983. A kukoricamoly és kártétele. Növényvédelem. 19. 11: 515-517.

Pepó, P.-Vad, A.-Berényi, S.: 2006a. Effect of some agrotechnical elements on the yield of maize on chernozem soil. Cereal Research Communications. 34. 1: 621-624.

Pepó P.-Tóth Sz.-Bódi Z.: 2006b. Kukoricavonalak és hibridjeik Fusarium ssp. és kukoricamoly (Ostrinia nubilalis Hübner) ellenállóságának vizsgálata diallél keresztezésben. Növénytermelés. 55. 1-2: 63-70.

Pepó P.-Vad A.-Berényi S.-Vad A.: 2008. Az öntözés hatása a kukorica (Zea mays L.) termésére száraz évjáratban csernozjom talajon. Növénytermelés. 57. 2: 171-179.

Princzinger, G.: 1996. Monitoring of western corn rootworm (Diabrotica virgifera virgifera LeConte) in Hungary. 1995. IWGO Newsletter. 16. 1: 7-11.

Princzinger, G.-Ripka, G.-Hataláné, Zs. I.-Hegyi, T.-Herczig, B.-Kleineizel, Sz.-Tóth, B.Vasas, L.-Vörös, G.: 2002. Present situation of the Western Corn Rootworm (Diabrotica virgifera virgifera LeConte) in Hungary. $9^{\text {th }}$ IWGO Diabrotica Subgroup Meeting and $8^{\text {th }}$ EPPO. 14-15.

Ripka G.-Princzinger G.-Hataláné Zs. I.-Hegyi T.-Tóth B.-Vasas L.-Vörös G.: 2000. Az amerikai kukoricabogár (Diabrotica virgifera virgifera LeConte) (Coleoptera: Chrysomelidae) felderítésével kapcsolatos hazai vizsgálatok eredményei. Állattani Közlemények. 85: 69-78.

Sárvári, M.: 2005. Impact of nutrient supply, sowing time and plant density on maize yield. Acta Agronomica Hungarica. 53. 1:59-70

Sárvári M.: 2009. A kukorica hibridspecifikus trágyázása és optimális tôszáma. Agrofórum Extra. 27: 40-45. 
Széll E.-Hataláné Zs. I.-Kádár A.: 2005. A kukoricabogár elleni védekezés tapasztalatai szabadföldi kísérletek eredményei alapján. Gyakorlati Agrofórum Extra. 10: 13-17.

A szerzők levelezési címe - Address of the authors:

Lente Ádám-Dr. Pepó Péter

Debreceni Egyetem AMTC

Növénytudományi Intézet

Debrecen

Böszörményi út 138.

$\mathrm{H}-4032$ 